\title{
Life history patterns of Procladius choreus, Tanypus punctipennis and Chironomus balatonicus in Lake Balaton
}

\author{
A. Specziár
}

Balaton Limnological Research Institute of the Hungarian Academy of Sciences, Klebelsberg K.u. 3., H-8237 Tihany, Hungary.

\begin{abstract}
Life history patterns of the three most abundant chironomids were analysed in Lake Balaton by monitoring the population dynamics of larvae and the presence of pupal exuviae. Procladius choreus had two generations per year with at least two parallel cohorts during 1996-1999. Tanypus punctipennis had a trivoltine life cycle with occasional parallel cohorts, overlapping generations and long, interrupted emergence periods between 1997 and 1999. At Tihany, Chironomus balatonicus had only one detectable generation between 1995 and 2002. Meanwhile at Keszthely, the abundance of C. balatonicus larvae peaked from autumn to the beginning of summer in 1996/1997, 1998/1999 and 2000/2001, and it was continuously high from August 2001 to October 2002. However, between these abundance peaks there were long periods when larvae could not be found at all. The extreme population dynamics of $C$. balatonicus suggests that living conditions may fluctuate around the limit of this species in Lake Balaton. Although C. balatonicus larvae practically were not found at both sampling sites from July 1997 to August 1998 , and from July 1999 to August 2000, sporadic occurrence of exuviae during these periods proves that refuge areas should exist within the lake. Possible background of the uncommon population dynamics of $C$. balatonicus is discussed.
\end{abstract}

Keywords : Chironomidae, life history, population dynamics, parallel cohorts, missed generations.

\section{Introduction}

Chironomids play an important role in lotic and lentic ecosystems by decomposing autochthonous and allochthonous detritus and as they are important foods for higher trophic levels, especially for fish. Thanks to the widespread distribution of the family and the specific environmental requirements of species, chironomids are good indicators of environmental status (Brundin 1958, Seather 1979, Wiederholm 1980). Life history pattern of chironomids may vary by climate, altitude, water depth, food resource and other environmental factors (Borutsky 1963, Tokeshi 1995). Therefore, life history data are important not only for production calculations (Benke 1984), but they also can give important information about environmental conditions, such about changes in food resources (Hooper et al. 2003), predation pressure by fish (Kajak \& Prus 2004), oxygen concentration (Jónasson \& Kristiansen 1967) and may indicate climate change (Péry \& Garric 2006).

* Corresponding author: E-mail: speci@tres.blki.hu
Benthos of Lake Balaton is dominated by three chironomid species, Procladius choreus (Meigen), Tanypus punctipennis Meigen and Chironomus balatonicus Dévai, Wülker et Scholl, that comprise more than $80-90 \%$ of the benthic chironomid fauna in biomass (Dévai \& Moldován 1983, Specziár \& Bíró 1998, Specziár \& Vörös 2001). During the 1980s and the first half of the 1990s several mass emergences occurred in the lake causing a considerable disinterest in tourism. These events drew the attention to the necessity of life history investigations that could facilitate the forecasting of mass emergences of chironomids. Such studies were initiated during the 1980s and they covered exuviae monitoring (Dévai 1988) and some laboratory observations on the development of $C$. balatonicus larvae (Dévai 1993). Specziár and Vörös (2001) found that parallel with the decreasing productivity of Lake Balaton, the occurrence of the large $C$. balatonicus larvae became inordinate, and periods with high larval density were alternated with several month long periods with actually zero abundance. The aim of this study was to describe life history patterns of the three dominant chironomids in Lake Balaton. In this study I analyse 
live cycle of midges based on the size frequency distribution of larvae and the presence of pupal exuviae on the water surface.

\section{Study area}

Lake Balaton is a large $\left(593 \mathrm{~km}^{2}\right)$ and shallow (average depth $3.25 \mathrm{~m}$ ) lake in Hungary situated at $46^{\circ}$ $42^{\prime}-47^{\circ} 04^{\prime} \mathrm{N}, 17^{\circ} 15^{\prime}-18^{\circ} 10^{\prime} \mathrm{E}$ and at $104.8 \mathrm{~m}$ above sea level. This slightly alkaline lake contains about 400 $\mathrm{mg} \mathrm{l}^{-1}$ of $\mathrm{Ca}^{2+}$ and $\mathrm{Mg}^{2+}\left(\mathrm{HCO}_{3}^{-}\right)$. A wind over 1 to $4 \mathrm{~m}$ $\sec ^{-1}$ velocity disturbs the loose sediment and disperses the solid particles in the whole water body. The natural shoreline (reed grass stands) has been limited to $110 \mathrm{~km}$. The remaining shoreline $(105 \mathrm{~km})$ has been artificially protected with stones or concrete walls and there are several harbors for sailboats and beaches. The water level has also been regulated and its annual fluctuation mostly does not reach more than $50 \mathrm{~cm}$. Lake Balaton is an important tourist centre. Consequently, heavy human pressure and cultural eutrophication have changed the biological structure and functioning of the whole lake during the mid 1900s. However, due to a successful nutrient management on the drainage area Lake Balaton has been recovering from this man-made eutrophication since the mid 1990s (Istvánovics et al. 2007). Oxygen deficiency has never been registered in the lake and also concentrations of heavy metals and other toxic pollutants are low or insignificant (Herodek et al. 1988, Nguyen et al. 2005). In most of the lake area, sediment of Lake Balaton is composed of very fine silt which grain size is $<0.2 \mathrm{~mm}$ but in $75 \%$ of the particles the grain size is $<0.0063 \mathrm{~mm}$. Sand (grain size: 0.063 $0.63 \mathrm{~mm}$ ) occurs only along the southern shoreline of the lake in an about $500 \mathrm{~m}$ wide very shallow and wind exposed littoral zone (Müller 1969). Organic matter content of the offshore sediment varies over the lake area between $2.4 \%$ and $8.6 \%$ in dry weight (Specziár \& Vörös 2001). Limnology of Lake Balaton was reviewed in details by Herodek et al. (1988) (see also Table 1.).

\section{Material and methods}

During 1995-2002 three (in 1995-1998) to five (in 1999-2002) sediment samples were taken weekly to four weekly at Tihany and at Keszthely (not in 1995) from the offshore area of Lake Balaton in the ice free period, from February to October (December) by means of a corer $\left(2 \times 62.2 \mathrm{~cm}^{2}\right.$ and $1 \times 109.8 \mathrm{~cm}^{2}$ per sediment sample in 1995-1996 and 1997-2002, respectively).
Sediment samples were washed through a sieve of $0.25 \mathrm{~mm}$ mesh-size in the field, and then taken to the laboratory in a cooling box where chironomids were separated from live samples by sugar flotation (Anderson 1959) and preserved in 3.5\% formaldehyde until further analyses. Larvae were separated to taxonomic groups and to instars. Second to fourth instars were distinguished according to the head capsule width of larvae (Specziár \& Bíró 1998). Length of each larva was measured to the nearest $0.1 \mathrm{~mm}$.

To monitor the emergence of chironomids, pupal exuviae were collected from the water surface with a dip-net of $0.25 \mathrm{~mm}$ mesh-size on every to every third day during the ice-free period at Tihany, and biweekly at Keszthely in 1996-1999. Since the method of pupal exuviae sampling was not quantitative thus we considered only presence-absence information on emergence. Life cycle analyses were performed for the period between 1996 and 1999 according to the length frequency dynamics of larvae by instars and the occurrence of pupal exuviae, while abundance dynamics of $C$. balatonicus larvae were described for the entire sampling period from 1995 to 2002.

\section{Results}

During the study, altogether 25 chironomid taxa were found as larva and 20 taxa as pupal exuvia (Specziár \& Bíró 1998, Bíró \& Specziár 2001). However, only three species, $P$. choreus, $T$. punctipennis and C. balatonicus, were abundant enough to perform life cycle analyses.

\section{Procladius choreus}

In 1996-1999, P. choreus dominated in abundance both at Tihany (564-872 ind. $\mathrm{m}^{-2}$, annual means) and Keszthely (316-538 ind. $\mathrm{m}^{-2}$, annual means) (see also Specziár \& Bíró 1998) and on an average it amounted 48.7-64.6\% of the total chironomid biomass (including all found species) at Tihany and 5.2-15.3\% at Keszthely. Seasonal variations of abundance showed mostly one coldwater (autumn to spring) and one summer peaks annually (Fig. 2.).

$P$. choreus had a bivoltine life cycle and most generations consisted of at least two contemporary cohorts (Fig. 3.). Presence of the parallel cohorts was obvious in overwintering generations, but it was less characteristic in summer generations. Life cycle was similar during the four year of study at both sampling sites. 
Table 1. Hydrological and limnological charachteristics of Lake Balaton (after Herodek et al. 1988, Specziár \& Vörös 2001).

\begin{tabular}{|c|c|c|c|}
\hline & Lake & $\begin{array}{l}\text { Keszthely } \\
\text { basin }\end{array}$ & $\begin{array}{l}\text { Tihany } \\
\text { basin }\end{array}$ \\
\hline Surface area $\left(\mathrm{km}^{2}\right)$ & 593 & & \\
\hline Volume $\left(\mathrm{km}^{3}\right)$ & 1.8 & & \\
\hline Maximum depth (m) & 11.2 & & \\
\hline Mean depth (m) & 3.25 & 2.28 & 3.68 \\
\hline Water residence time (years) & 4.71 & 0.28 & 1.98 \\
\hline Catchment area $\left(\mathrm{km}^{2}\right)$ & 5182 & & \\
\hline Tributary inflow $\left(10^{6} \mathrm{~m}^{3} \mathrm{yr}^{-1}\right)$ & 577 & 307 & 27 \\
\hline $\begin{array}{l}\text { Mean annual water } \\
\text { temperature }\left({ }^{\circ} \mathrm{C}\right)\end{array}$ & 12.2 & & \\
\hline $\mathrm{pH}$ & $8.2-9.1$ & $(6.8) * 8.2-9.1$ & $8.2-9.1$ \\
\hline Conductivity $(\mu \mathrm{s} / \mathrm{cm})$ & $550-671$ & $550-651$ & $605-671$ \\
\hline $\begin{array}{l}\text { Dissolved oxygen near } \\
\text { the bottom }\left(\mathrm{mg} \mathrm{l}^{-1}\right)\end{array}$ & 4.2-9.9 & $4.2-9.1$ & $6.1-9.6$ \\
\hline Primary production $\left(\mathrm{gC} \mathrm{m}^{-2} \mathrm{yr}^{-1}\right)$ & & $166-554$ & $125-252$ \\
\hline $\begin{array}{l}\text { Organic matter content of the upper } \\
1 \mathrm{~cm} \text { of the sediment (\% dry wt) }\end{array}$ & $2.4-8.6$ & 4.4-8.6 & $4.9-7.4$ \\
\hline
\end{tabular}

* In some periods at the inlet of Zala River.

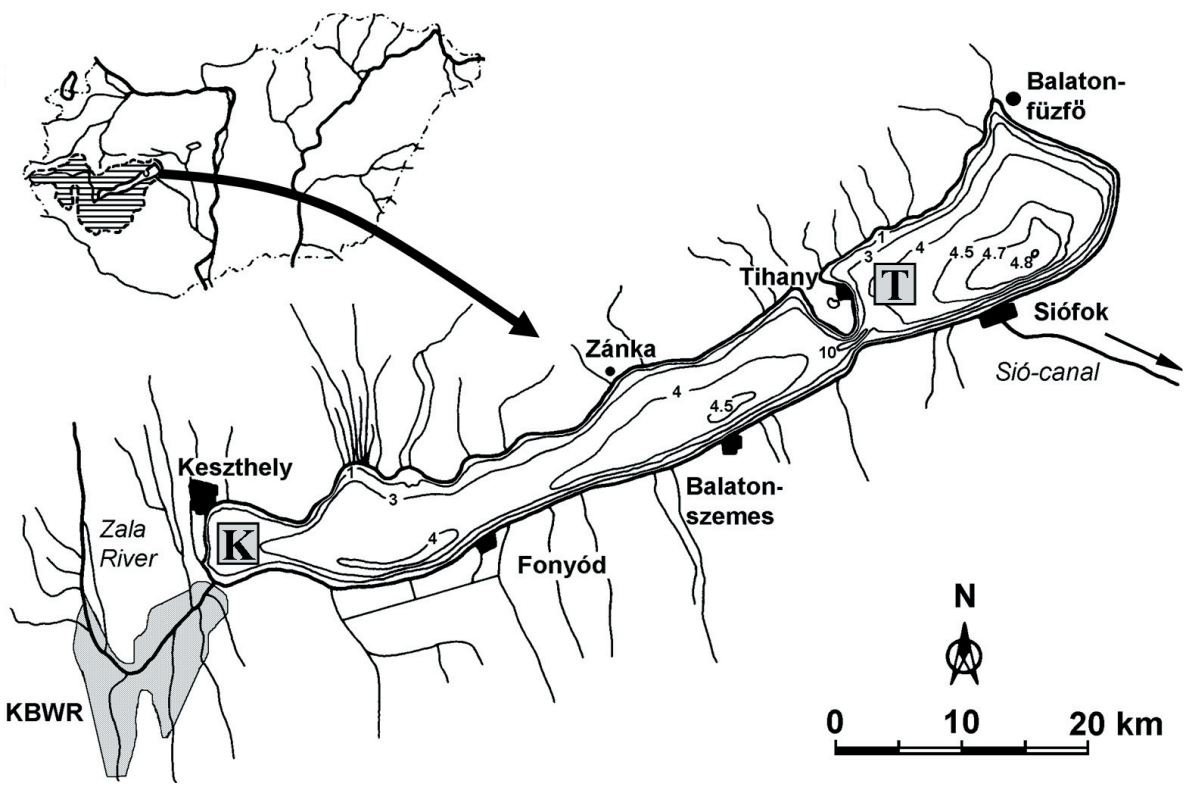

Fig. 1. Map of Lake Balaton (Hungary) and its drainage area. Samplings were done near Tihany (T) and Keszthely (K). KBWR - Kis-Balaton Water Quality Protecting Reservoir. 

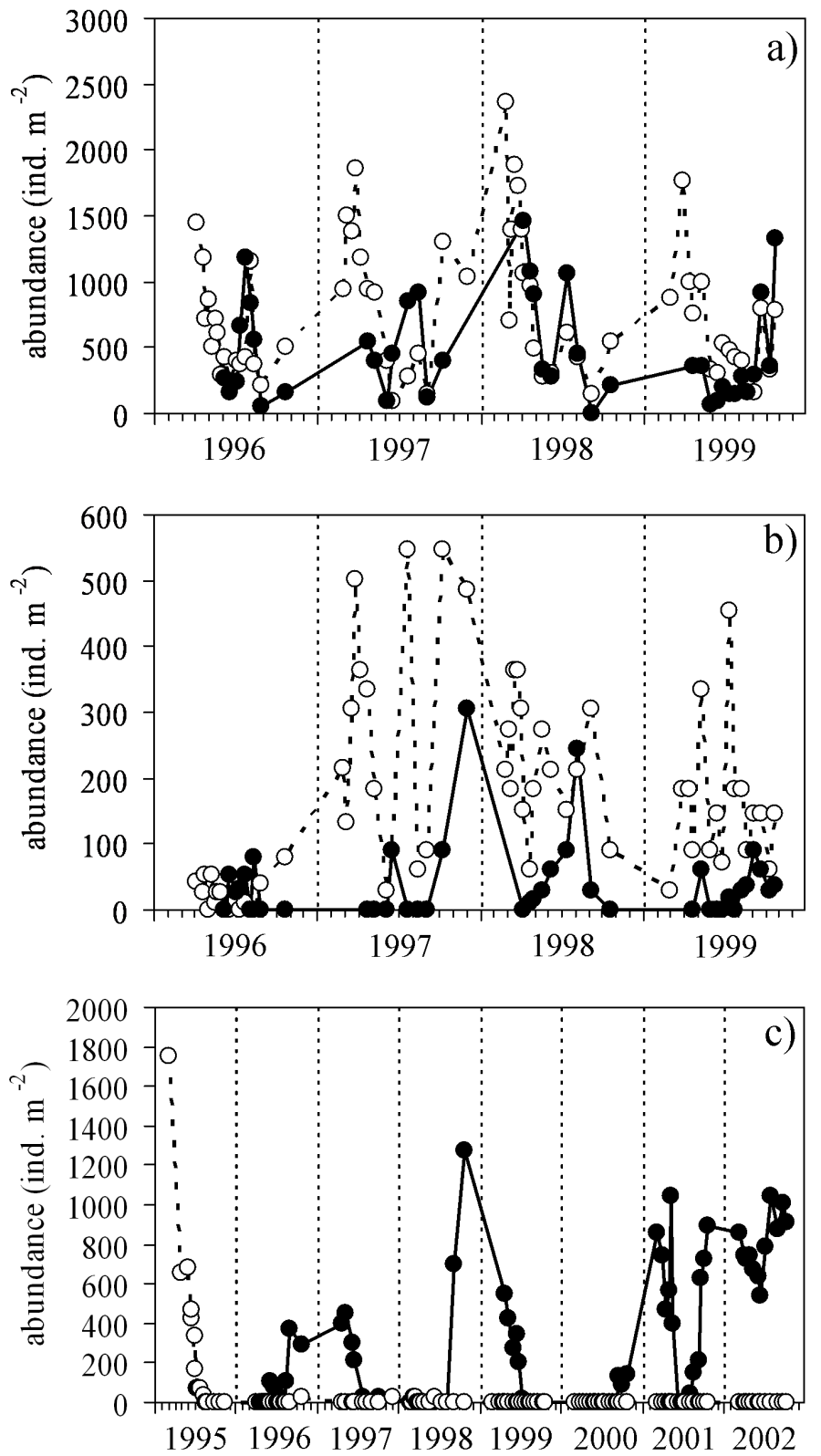

Fig. 2. Abundance dynamics of Procladius choreus (a), Tanypus punctipennis (b) and Chironomus balatonicus (c) at Tihany (open circle with dotted line) and Keszthely (filled circle with continuous line). Standard deviations were omitted.

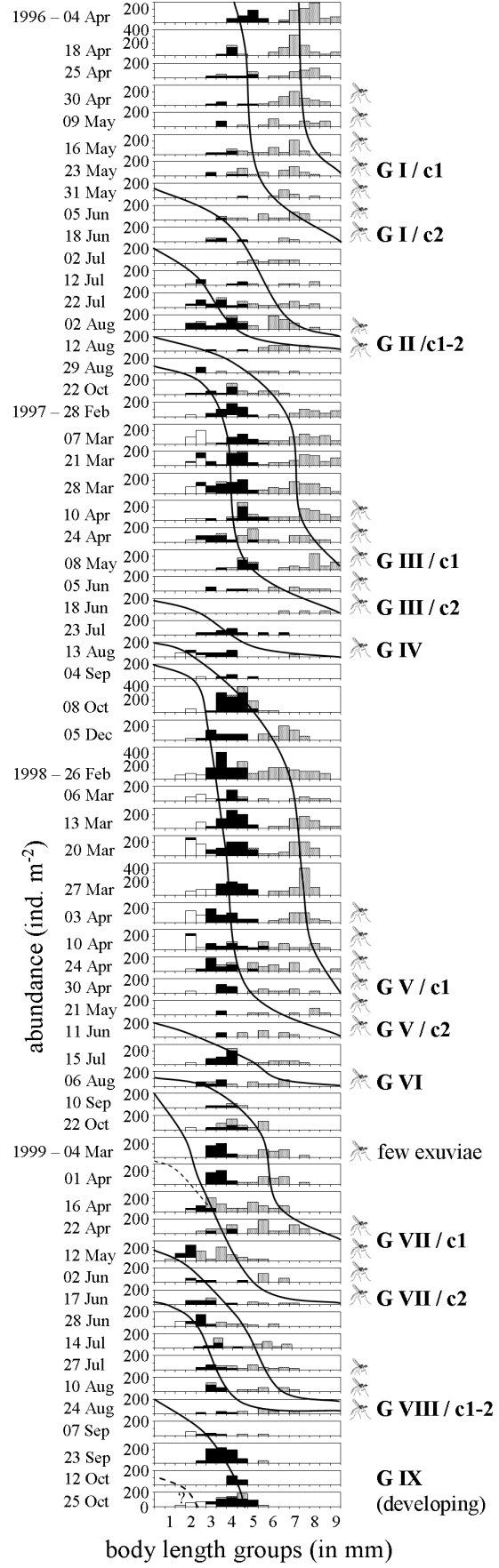

Fig. 3. Size frequency dynamics and life cycle of Procladius choreus at Tihany. Assumed cohort lines are indicated. Empty bars represent second, filled bars third and dotted bars fourth larval instars. Emergence periods are indicated with symbols figuring adult midges. $\mathrm{G}$ - generation, $\mathrm{c}$ - cohort, $\mathrm{e}$ - emergence. 
Larvae overwintered mainly as third and fourth instars although few second instar larvae were also found. Emergence of the winter generation lasted from May to June, occasionally to the beginning of July. Pupal exuviae were not found before April except in 1999. Most intense emergences of the winter generation occurred generally at the beginning of June. Summer generation started to develop only after this mass emergence. Emergence of the summer generation was more synchronised in 1996-1998, and it lasted only for two to three weeks in August. However, exuviae were also found throughout July in 1999. At the end of October 1999 some second instar larvae appeared in the sediment which might indicate an autumn emergence, too. However, this was not supported neither by the occurrence of pupal exuviae nor by the presence of large fourth instar larvae.

\section{Tanypus punctipennis}

In 1996, T. punctipennis larvae were found in low density (22-27 ind. $\mathrm{m}^{-2}$, annual means) at both sampling sites, thus the life cycle could not be analysed. In 19971999, the density of T. punctipennis larvae increased significantly being 159-306 ind. $\mathrm{m}^{-2}$ (annual means) at Tihany and 28-80 ind. $\mathrm{m}^{-2}$ (annual means) at Keszthely (see also Specziár \& Bíró 1998). In this period, the average contribution of this species to the total chironomid biomass was $26.2-32.7 \%$ (annual means) at Tihany and $0.9-2.0 \%$ at Keszthely. Larval abundance showed different patterns at the two sampling sites and also varied among years, but in general it had two to three peaks annually (Fig. 2.).

According to the size frequency dynamics of larvae, we could separate altogether 11 cohorts between 1997 and 1999 at Tihany, which could be corresponded to ten generations. $T$. punctipennis had three generations per year with two (in 1997/1998) or one winter cohorts, respectively (Fig. 4.). In 1997, emergence of the first winter cohort started in February just after the thaw. However, most of the overwintered larvae emerged from April to June. In 1997, the first summer generation emerged in June, while the second during AugustSeptember. In 1998-1999, winter cohorts emerged from February to April or to the first half of May (in 1999). Individuals of the first summer generation emerged from May to June and that of the second summer generation emerged from July but mainly in AugustSeptember. Larvae overwintered dominantly as fourth instars, and only few of them as third instars.

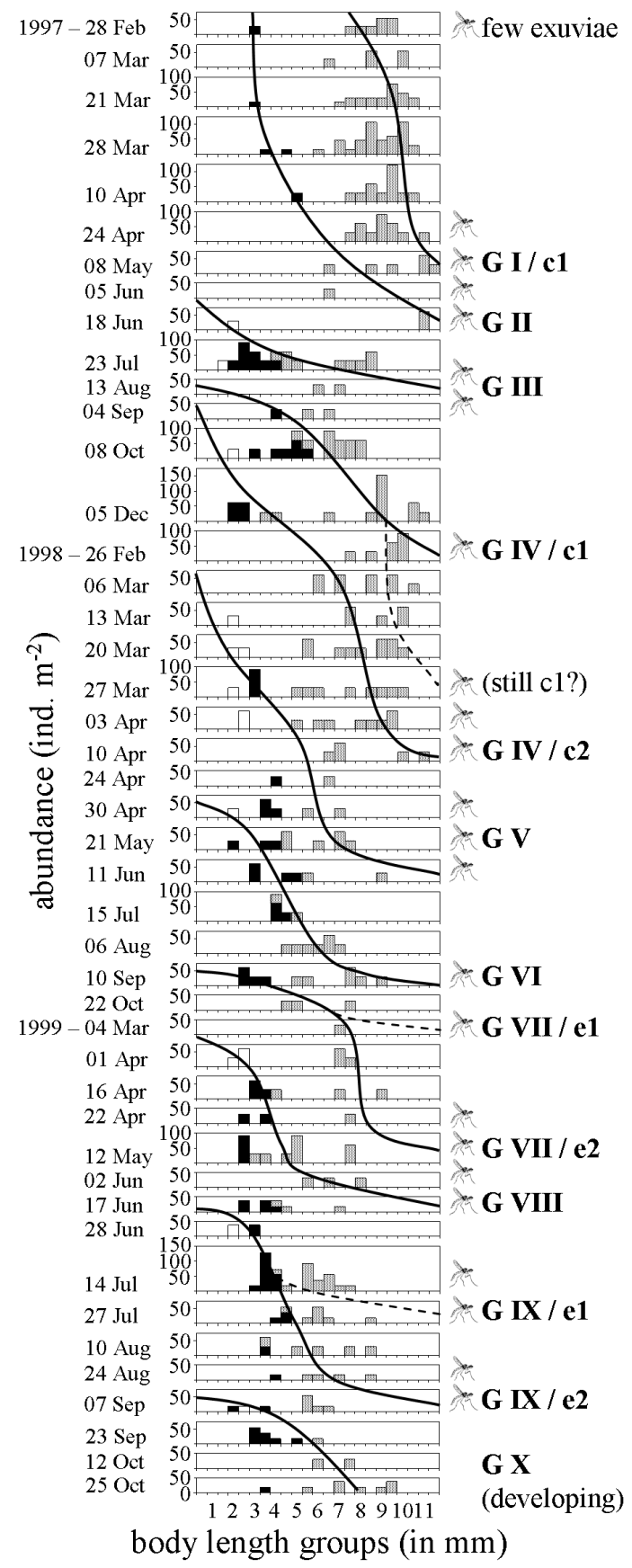

Fig. 4. Size frequency dynamics and life cycle of Tanypus punctipennis at Tihany. Assumed cohort lines are indicated. Empty bars represent second, filled bars third and dotted bars fourth larval instars. Emergence periods are indicated with symbols figuring adult midges. $\mathrm{G}$ - generation, $\mathrm{c}$ - cohort, e - emergence. 


\section{Chironomus balatonicus}

At Tihany, the maximum offshore density of $C$. balatonicus was 1751 ind. $\mathrm{m}^{-2}$ in February 1995, and the mass swarming of adults caused significant nuisance during May and June 1995. Between 1996 and 2002, C. balatonicus practically occurred only at Keszthely in a density of 23-796 ind. $\mathrm{m}^{-2}$ (annual means) and where it comprised $80.0-91.9 \%$ of the mean total chironomid biomass (see also Specziár \& Bíró 1998). At Keszthely, the abundance of larvae peaked from autumn to the beginning of summer in 1996/1997, 1998/1999 and 2000/2001, and it was continuously high from August 2001 to October 2002. However, between these abundance peaks there were long periods when larvae could not be found at all (Fig. 2.).

In 1995, C. balatonicus had one detectable generation at Tihany, which was an overwintering generation and probably it was established still in autumn 1994 (Fig. 2.). Pupal exuviae occurred from 20 April to 15 July, with two marked peaks from 1 to 5 May and from 8 to 9 July. Since the end of July 1995 C. balatonicus larvae and pupal exuviae have been found only sporadically at Tihany. During 1996-1999, C. balatonicus had only three detectable generations at Keszthely with eight to ten months developing periods (Fig. 5.). Between these generations there were two and fourteen months gaps without detectable populations in 1996 and 1997-1998, respectively. Detectable generations were established in September. Larvae overwintered as third and fourth instars. Pupal exuviae of $C$. balatonicus were found from May to the middle of July, with maximum densities at the end of June and the beginning of July, although very few exuviae also occurred from August to October. From July 1999 no $C$. balatonicus larvae were found again until August 2000, when after a 14 months of virtual absence the next detectable generation initiated. However, live cycle was not studied in 2000-2002.

\section{Discussion}

Present results on the voltinism of $P$. choreus coincide with the observations of Dévai (1988), who also found two emergence peaks in Lake Balaton during May to June and in August. Other populations of $P$. choreus generally also have a bivoltine life cycle (Learner \& Potter 1974, Pankratova 1977), although in Lake Banyoles even four generations per year were found (Prat \& Rieradevall 1995). Similarly to Lake Balaton, contemporary winter cohorts were found in Procladius spp. in Lake Erken (Goedkoop \& Johnson 1996).

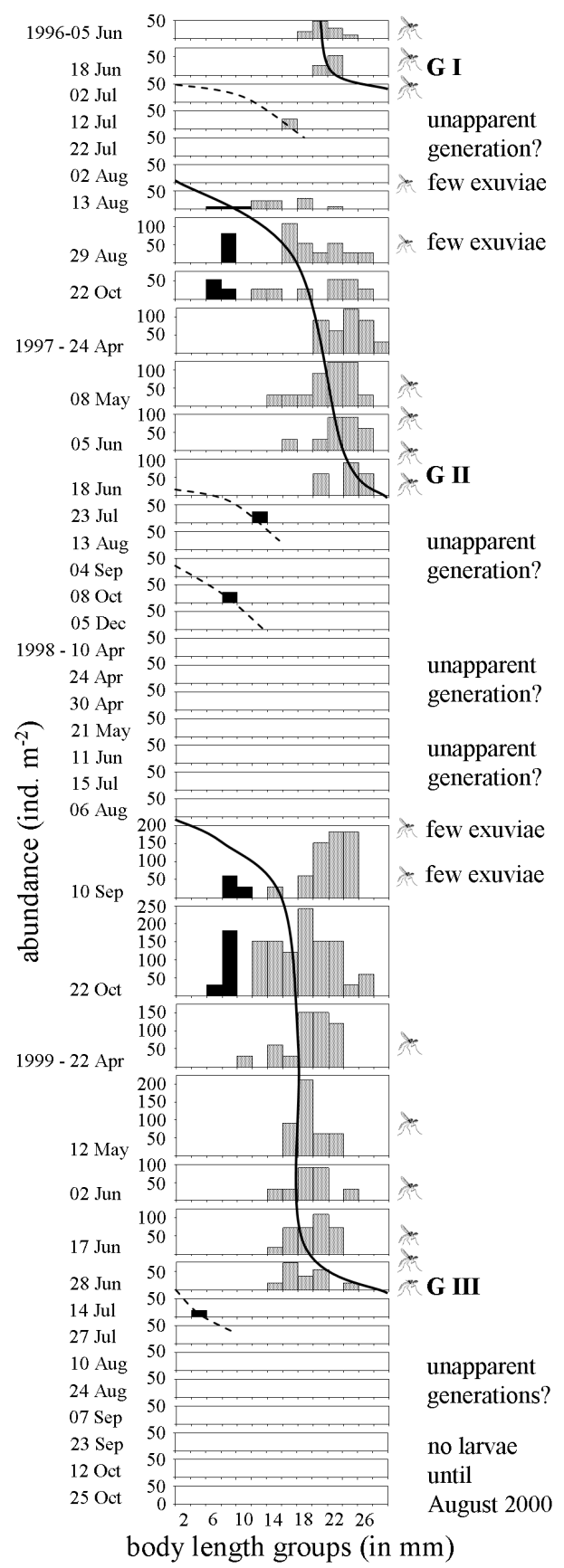

Fig. 5. Size frequency dynamics and life cycle of Chironomus balatonicus at Keszthely. Assumed cohort lines are indicated. Empty bars represent second, filled bars third and dotted bars fourth larval instars. Emergence periods are indicated with symbols figuring adult midges. $\mathrm{G}$ - generation, $\mathrm{c}$ - cohort, e - emergence. 
In T. punctipennis two generations per year with two parallel winter cohorts were found in the Neusiedler See (Wolfram 1996), two to three generations in Lake Banyoles (Prat \& Rieradevall 1995) and one to two in Essendon ponds (Learner \& Potter 1974). In Lake Balaton, the population dynamics of $T$. punctipennis suggests a trivoltine life cycle with occasional parallel cohorts, overlapping generations and prolonged emergence periods. A previous study reported two major emergence periods, in June and September, in $T$. punctipennis in Lake Balaton (Dévai 1988). These two emergence periods agree with the emergence periods of the two summer generations found in the present study. However, we found that the overwintering generation typically emerges from February to April.

Under the temperate climate Chironomus species generally have two generations per year (e.g., Borutsky 1963, Sokolova 1983). However, Dévai (1993) found that under laboratory conditions $C$. balatonicus larvae accomplished their development in 15-20 days at 20$22^{\circ} \mathrm{C}$. Short generation times were also found in 1983 at Keszthely when four consecutive generations of $C$. balatonicus were assumed according to the emergence pattern and the abundance dynamics of larvae (Dévai 1990). However, the population dynamics of $C$. balatonicus was very uncommon during this study. According to our best knowledge similar population dynamics has not been reported yet. All detectable generations found between 1996 and 2001 were winter generations and according to observations in 1996/1997 and 1998/1999 they developed for eight to ten months. Meanwhile larvae were not found for two to fourteen months, and the only season with significant larval abundance in summer was 2002. Results of other, parallel investigations with much more sampling sites over the lake also proved the lack of $C$. balatonicus larvae during the herein mentioned periods (Specziár \& Bíró 1998, Bíró \& Specziár 2001, Specziár \& Vörös 2001). On the other hand, sporadic occurrence of exuviae during these periods (it is easier to find exuviae visually on the water surface than to sample rare larvae in the sediment) proves that refuge areas should exist in the lake where few larvae can develop. Expansive stockings of $C$. balatonicus might be made by these "hidden populations" when living conditions became adequate in the lake. Because of the extreme population dynamics, voltinism of $C$. balatonicus can not be determined, but according to the available information it could be supposed that this species had at least two generations annually of which the summer generation(s) was(were) hidden.

Extreme population dynamics of $C$. balatonicus suggests that living conditions in Lake Balaton fluctuate around the limit value of this species. Specziár and Vörös (2001) showed that production of C. balatonicus strongly depends on the phytoplankton production. It was concluded that the winter generation of $C$. balatonicus achieves the detectable density if late summer mean chlorophyll-a concentration exceeds 20-30 $\mathrm{mg} \mathrm{m}^{-3}$ or in other approach the phytoplankton production exceeds $250 \mathrm{~g} \mathrm{C} \mathrm{m}^{-2} \mathrm{yr}^{-1}$. However, sporadic occurance of $C$. balatonicus pupal exuviae even during periods when larvae could not been found, suggests that other factors could also impact the distribution of this species in Lake Balaton. Consequently, investigation of the "hidden populations" and their environment could be a special chance to learn more about the ecology of C. balatonicus.

All three chironomid species considered in this study had long emergence periods, especially in their winter generations. Prolonged emergence in chironomids is common even in laboratory reared unicohort stocks (Fisher 1974, Maténa 1989). For example Maténa (1989) found that hatching of laboratory reared $C$. plumosus lasted from the $21^{\text {th }}$ day until the $100^{\text {th }}$ day of rearing. It is obvious though that under natural conditions emergence of a generation, especially that of with parallel cohorts, may last still longer. Long emergence periods may favour the formation of parallel cohorts, which could reduce inter- and intraspecific competition, especially in Tanypodinae where diet shift may occur during the ontogeny (Baker \& McLachlan 1979, Schiemer 1979).

Parallel cohorts in the two Tanypodinae species separated most clearly in winter generations. This also could be a consequence of the diapause that may last for a long period in winter. If parts of a generation enter diapause in different developmental stage or time the generation splits into cohorts (Goddeeris 1989). During the diapause the ontogeny of larvae stops, thus they remain in the same larval stage, however their somatic growth may continue (Goddeeris et al. 2001). Accordingly, larvae may grow larger in winter that is in accordance with the present observations as overwintered individuals of the three chironomid species reached larger sizes compared to individuals of the summer generations. According to the population dynamics of larvae it could be assumed that overwintering $P$. choreus and $C$. balatonicus larvae enter diapause in third and fourth instars, while $T$. punctipennis larvae mainly as fourth instars.

In conclusion, the most important finding of this study is the uncommon present-absence population dynamics 
of $C$. balatonicus in Lake Balaton. Similar phenomenon has not been observed in other invertebrates in the lake yet. Alteration of high density and undetectable generations suggests that this species is particularly sensitive to certain environmental factors, and therefore, it can be a good indicator species. However, the ecological role and environmental tolerance of $C$. balatonicus is still not known adequately.

\section{Acknowledgements}

I thank Béla Szecsödi and Géza Dobos for their help in the field and Dr. Kálmán Bíró for his advices during the study. This study was supported by the Office of Prime Minister of Hungary (MEH).

\section{References}

Anderson R.O. 1959. - A modified flotation technique for sorting bottom fauna samples. Limnol. Oceanogr., 4, 223-225.

Baker A.S. \& McLachlan A.J. 1979. - Food preferences of Tanypodinae larvae (Diptera: Chironomidae). Hydrobiologia, 62, 283-288

Benke A.C. 1984. - Secondary production of aquatic insects. Pages 289-322 in The ecology of aquatic insects. Resh V.H. \& Rosenberg D.M. (eds). Praeger Publishers, New York.

Bíró K. \& Specziár A. 2001. - Contribution to the knowledge of Lake Balaton's chironomid fauna (Diptera, Chironomidae). Hidrol. Közl., 81 (5-6), 322-325. (in Hungarian).

Borutsky E.V. 1963. - Emergence of Chironomidae (Diptera) imagines from continental waterbodies of different climatic belts as a factor of food supply of fishes. Zool. Zh., 42, 233-247. (in Russian).

Brundin L. 1958. - The bottom faunistical lake type system and its application to the southern hemisphere. Moreover a theory of glacial erosion as a factor of productivity in lakes and oceans. Verh. Int. Verein. Limnol., 13, 288-297.

Dévai G. 1988. - Emergence patterns of chironomids in Keszthelybasin of Lake Balaton (Hungary). Spixiana (Suppl.), 14, 201-211.

Dévai G. 1990. - Ecological background and importance of change of chironomid fauna (Diptera: Chironomidae) in shallow Lake Balaton. Hydrobiologia, 191, 189-198.

Dévai G. 1993. - Production studies on the larvae of Chironomus balatonicus. Abstr. Bot., 17, 261-265.

Dévai G. \& Moldován J. 1983. - An attempt to trace eutrophication in a shallow lake (Balaton, Hungary) using chironomids. Hydrobiologia, 103, 169-175.

Fisher J. 1974. - Experimentelle Beiträge zur Ökologie von Chironomus (Diptera). - I. Dormanz bei Chironomus nuditarsis und Chironomus plumosus. Oecologia (Berl.), 16, 73-95.

Goddeeris B.R. 1989. - A methodology for the study of the life cycle of aquatic Chironomidae (Diptera). Verh Symp "Invertebraten van Belgie”, K. B. I. N., Brussel, 379-385.

Goddeeris B.R., Vermeulen A.C., De Geest E., Jacobs H., Baert B. \& Ollevier F. 2001. - Diapause induction in the third and fourth instar of Chironomus riparius (Diptera) from Belgian lowland brooks. Arch. Hydrobiol., 150, 307-327.

Goedkoop W. \& Johnson R.K. 1996. - Pelagic-benthic coupling: Profundal benthic community response to spring diatom deposition in mesotrophic Lake Erken. Limnol. Oceanogr., 41, 636-647.

Herodek S., Laczkó L. \& Virág Á. 1988. - Lake Balaton: research and management. Nexus, Budapest, $110 \mathrm{p}$.

Hooper H.L., Sibly R.M., Hutchinson T.H. \& Maund S.J. 2003. - The influence of larval density, food availability and habitat longevity on the life history and population growth rate of the midge Chironomus riparius. Oikos, 102, 515-524.

Istvánovics V., Clement A., Somlyódy L., Specziár A., G.-Tóth L. \& Padisák J. 2007. - Updating water quality targets for shallow Lake Balaton (Hungary), recovering from eutrophication. Hydrobiologia, 581, 305-318.

Jónasson P.M. \& Kristiansen J. 1967. - Primary and secondary production in Lake Esrom. Growth of Chironomus anthracinus in relation to seasonal cycles of phytoplankton and dissolved oxygen. Int. Revue ges. Hydrobiol., 52, 163-217.

Kajak Z. \& Prus P. 2004. - Time of Chironomus plumosus (L.) generations in natural conditions of lowland reservoir. Pol. J. Ecol., 52, 211-222.

Learner M.A. \& Potter D.W.B. 1974. - The seasonal periodicity of emergence of Insects from two ponds in Hertfordshire, England, with special reference to the Chironomidae (Diptera: Nematocera). Hydrobiologia, 44, 495-510.

Maténa J. 1989. - Seasonal dynamics of Chironomus plumosus (L.) (Diptera, Chironomidae) population from a fish pond in southern Bohemia. Int. Revue ges. Hydrobiol., 74, 599-610.

Müller G. 1969. - Sedimentbildung im Plattensee, Ungarn. Naturwissenshaften, 56, 606-615.

Nguyen H.L., Leermakers M., Osán J., Török S. \& Baeyens W. 2005. Heavy metals in Lake Balaton: water column, suspended matter, sediment and biota. Sci. Total Environ., 340, 213-230.

Pankratova V.Ya. 1977. - [Larvae and pupae of chironomids of the subfamilies Podonominae and Tanypodinae in fauna SSSR]. Nauka, Saint Petersburg, 156 p. (in Russian).

Péry A.R.R. \& Garric J. 2006. - Modelling effects of temperature and feeding level on the life cycle of the midge Chironomus riparius: an energy-based modelling approach. Hydrobiologia, 553, 59-66.

Prat N. \& Rieradevall M. 1995. - Life cycle and production of Chironomidae (Diptera) from Lake Banyoles (NE Spain). Freshwat. Biol., 33, 511-524.

Schiemer F. 1979. - The benthic community of the open lake. Pages 337-384 in Neusiedlersee: The limnology of a shallow lake in Central Europe, Löffler H. (ed.). Dr W. Junk Publisher, The Hague.

Seather O.A. 1979. - Chironomid communities as water quality indicators. Holarctic Ecol., 2, 65-74.

Sokolova N.Yu. (ed.) 1983. - Motyl Chironomus plumosus L. (Diptera, Chironomidae). Systematics, morphology, ecology, production. Nauka, Moscow, $310 \mathrm{p}$.

Specziár A. \& Bíró P. 1998. - Spatial distribution and short-term changes of benthic macrofauna in Lake Balaton (Hungary). Hydrobiologia, 389, 203-216.

Specziár A. \& Vörös L. 2001. - Long term dynamics of Lake Balaton's chironomid fauna and its dependence on the phytoplankton production. Arch. Hydrobiol., 152, 119-142.

Tokeshi M. 1995. - Life cycles and population dynamics. Pages 225268 in The Chironomidae. The biology and ecology of non-biting midges. Armitage P.D., Cranston P.S. \& Pinder L.C.V., Chapman $\&$ Hall, London.

Wiederholm T. 1980. - Chironomids as indicators of water quality in Swedish lakes. Acta. Univ. Carol. - Biol., 1978, 275-283.

Wolfram G. 1996. Distribution and production of chironomids (Diptera: Chironomidae) in a shallow, alkaline lake (Neusiedler See, Austria). Hydrobiologia, 318, 103-115. 